\title{
Geeniteknologian hyödyt ja kustannukset: tutkimus perunasta
}

\author{
Jussi Tuomisto
}

MTT Taloustutkimus.Luutnantintie 13,00410 HELSINKI.jussi.tuomisto@mtt.fi

\begin{abstract}
Johdanto
Suomessa viljellään perunaa vuosittain noin 30000 hehtaarin alalla. Perunan tuotantoala on pienentynyt 13 prosenttia kymmenessä vuodessa. Samaan aikaan hehtaarisadot ovat nousseet 22 prosenttia. Perunaa tuottavien tilojen lukumäärä on myös nopeasti vähentynyt. Vuodesta 1993 vuoteen 2001 perunaa tuottavien tilojen lukumäärä väheni 19 prosenttia. Monet pienet monitoimitilat ovat luopuneet perunantuotannosta ja perunantuotanto on keskittynyt tilakooltaan suuremmille ja päätoimisille perunanviljelytiloille. Perunantuotannon rakennekehitys on seurannut maatalouden yleistä rakennekehitystä. Perunantuotanto on samalla keskittynyt pääasiassa Etelä-Pohjanmaan, Pohjanmaan, Pohjois-Pohjanmaan ja Satakunnan TE-keskusten alueille, jossa tuotetaan 72 prosenttia Suomen perunasta.
\end{abstract}

Tuotannon tehostuminen vaatii yleensä teknologisia innovaatioita avuksi, joiden avulla tuotanto tapahtuu tehokkaammin kuin aikaisemmin. Teknologiset uudistukset vähentävät työvoiman käyttöä ja pääomavaltaistavat tuotantoa. Toisaalta uudistukset hyödyttävät yleensä enemmän suuria kuin pieniä yrityksiä. Samoin teknologiset uudistukset ovat epätasaisesti viljelijöiden saatavilla, olipa sitten kysymys tilakoko, tilojen sijainti, tuotantohaara tai henkinen pääoma (Virolainen 2001). Useat tutkimukset alleviivaavat, että taloudelliset hyödyt omaksua uusi teknologia eroavat laajasti tilojen välillä (Bullock \& Nitsi 2001, McBride \& Books 2000, Desquilbet, ym. 2001). Pienten yritysten uuden innovaation käyttöönottokyky on useissa tutkimuksissa todettu suurempia yrityksiä heikommaksi (Galbraith 1995). Syynä ovat $\mathrm{mm}$. skaalaedut, informaation puutteellisuus, epätäydelliset markkinat, epäedulliset markkinarakenteet ja harjoitettu politiikka jne. Toisaalta pienemmät tilat ovat voineet tavoitella ns. pelivarahyötyjä (economics of scope), keskittymällä laatuun, tilaustyöhön, paikallisiin palveluihin ja tuotannon joustavuuteen. (Niemi, ym. 2003).

Maataloudessa uudistusten merkitys on ollut suuri. Uuden teknologian johdosta ihmistyövoiman tarve on vähentynyt, uudet kasvilajikkeet, kemialliset kasvinsuojeluaineet ja lannoitteet ovat nostaneet satoja ja parantaneet riskinhallintakykyä (Virolainen 2001). 1990-luvulla geeniteknologian tuomat uudistukset tulivat mahdolliseksi maataloussektorille. Suomessa ei toistaiseksi kuitenkaan käytetä geenitekniikkaa hyväksi maa- ja elintarviketuotannossa, eikä geenimuunneltuja lajikkeita viljellä kaupalliseen myyntiin. Geenimuunneltujen kasvien viljely on mahdollista ainoastaan tutkimustarkoituksiin. Euroopassa tilanne on jokseenkin samanlainen; gm-tuotteet ovat harvinaisia kaupan hyllyillä ja kuluttajien vastustus on vankkaa. (Niemi, ym. 2003). Yhdysvalloissakaan ei geenimuunneltu peruna ole käytännön viljelyksessä, koska kansalaisvastustuksen aiheuttama julkinen paine on estänyt geenimuokatun perunan kaupallistamisen. Tosin Yhdysvalloissa gm-hyväksytyt puuvilla, maissi ja soija ovat yleisiä (Thill 2003). Geenimuokattua perunan siemenainesta on kuitenkin jo olemassa ja biologista tutkimusta sen mahdollisuuksista on tehty jonkin verran. Geenimuunnellut lajikkeet tullaan ottamaan heti käyttöön kun geenimuokattujen tuotteiden kaupallinen myynti sallitaan edes rajoitetusti (Cockburn \& Tencalla 2003, Thill 2003). Tilanteessa, jossa EU:ssa hyväksyttäisiin edes osittainen gm-tuotteiden kaupallinen myynti, lienee kuitenkin mahdotonta, että Suomesta voisi tulla gm-vapaa alue, koska pidemmän päälle tuontia on mahdoton estää. Ei ole mahdollista, että esimerkiksi Ruotsissa tai Virossa viljeltäisiin gm-perunaa ja Suomessa ei.

\begin{abstract}
Aineisto ja menetelmät
Geeniteknologia ei ole pelkkä yksittäinen kokonaisuus, jonka teknologisia seurauksia voitaisiin käsitellä yhtenä ryhmänä. Tällä hetkellä geeniteknologiset keksinnöt jaetaan kolmeen ryhmään, ns. ensimmäisen, toisen ja kolmannen aallon innovaatioihin. Ensimmäisen aallon teknologiassa puhutaan pelkästään agronomisista hyödyistä. Tällöin tarkastellaan, miten geeniteknologia alentaa tuotannon yksikkökustannuksia joko lisäämällä satoja, vähentämällä käytettävää panosmäärää tai muuttamalla panosten suhteellista käyttöä. Toisen aallon geeniteknologian päämääränä on parantaa tuotteen laatua. Tämä voi tapahtua esimerkiksi parantamalla ruuan makua, rakennetta, säilyvyyttä, ravintoarvoa tai ulkonäköä. Kolmannen aallon teknologialla on tarkoitus valjastaa geeniteknologia lääkeainetuotantoon. Tällöin tavoitteena on geeniteknologian avulla saada kasvit tuottamaan jotain
\end{abstract}


lääketeollisuuden raaka-ainetta. Geeniteknologian eri aalloilla on luonnollisesti erilainen vaikutus niin viljelijöihin kuin elintarvikeketjun muihinkin osapuoliin.

Tässä tutkimusraportissa tarkastellaan ainoastaan geeniteknologialla saavutettavien agronomisten hyötyjen, eli ensimmäisen asteen innovaatioiden vaikutuksia perunanviljelyn kannattavuuteen. Tutkimus on rajattu pelkästään torjunta-aineiden käytön ja niiden aiheuttamien kustannusten selvittämiseen perunanviljelyksessä sekä arviointeihin, miten geeniteknologian avulla voidaan näitä kustannuksia alentaa. Geeniteknologian taloudellisia vaikutuksia selvitettiin tilamallilaskelmien avulla. Tilamallien pohjatietoina käytettiin aikaisempia tutkimuksia $(\mathrm{mm}$. Tuomisto 2003, Tuomisto ja Antila 2001, Turunen 2001). Tutkimusaineistoa geeniteknologian mahdollisuuksista kerättiin haastatteluin, alan kirjallisuudesta, artikkeleista, seminaarijulkaisuista ja osallistumalla seminaareihin (mm. ICABR Conference). Tilastoaineistoa kerättiin Kasvintuotannon tarkastuskeskuksesta (KTTK), Maatalouden tietopalvelukeskuksesta (TIKE), Kemiralta ja Berneriltä.

\section{Tulokset ja tulosten tarkastelu}

Suomessa käytetään perunanviljelyksessä vuosittain keskimäärin 300 tonnia torjunta-aineita. Täsmällistä lukua on vaikea määrittää, koska joitakin perunalle tarkoitettuja torjunta-aineita käytetään myös öljykasvien tai erikoiskasvien viljelyksessä. Perunanviljelijät käyttävät torjunta-ainehankintaan noin 8,2 miljoonaa euroa vuodessa. Tästä pelkästään rutontorjunta-aineiden osuus on 46 prosenttia, eli 3,8 miljoonaa euroa. Torjunta-ainekustannus on tilakoosta ja sopimustuotannon mallista riippuen siemenperunantuotannossa 6 prosenttia, ruokaperunantuotannossa 4 prosenttia ja tärkkelysperunantuotannossa 4,5 prosenttia perunantuotannon tuotantokustannuksesta (Tuomisto 2003, Tuomisto ja Antila 2001, Turunen 2001).

Torjunta-aineiden käytöstä huolimatta kasvinsuojelussa ilmenee ongelmia. Esimerkiksi Kasvintuotannon tarkastuskeskuksen (KTTK) tilastojen mukaan satovuosina 1998-2002 siemenperunan kasvustotarkastuksissa keksimäärin 8,5 prosenttia joko hylättiin tai niissä siemenluokka aleni. 3,3 prosenttia oli tyvimädästä (Erwinia carotovora) ja 0,2 prosenttia perunaseitistä (Rhizoctonia solani) johtuvaa. Virustesteissä hylättiin 0,2 prosenttia tarkastetuista perunoista ja 2,5 prosentilla tarkastuksissa siemenluokka aleni. Vaarallisten kasvintuhoojien testeissä löytyi bakteerin (Clavibacter michiganensis ssp. sepedonicus) aiheuttamaa rengasmätää satovuosina 1998-2002 kolmelta tilalta. Tämä oli 0,1 prosenttia tehdyistä siementarkastuksista. Varastotarkastuksissa hylättiin keskimäärin 3,6 prosenttia tarkastetusta siemenperunasta. Hylätyistä kuusi prosenttia oli kuiva- tai märkämädästä, 15 prosenttia perunaruvesta ja seittiruvesta ja kuusi prosenttia maltokaariviruksesta johtuvaa.

Geenitekniikalla on viruksenkestävyys helppo jalostaa, mutta perunan jalostaminen monimutkaisia sienitauteja vastaan on ongelmallisempaa (Hofvander 2001). Suomessa tavattavat kirvojen levittämät virukset ovat perunan A-, M-, S- ja Y-virus. Virus saattaa pahimmillaan aiheuttaa jopa 50 prosentin satotappion (Tiilikkala 1993). Virustauteja voidaan torjua estämällä niiden levittäjäkirvoja siirtämään virusta kasvista toiseen. Tämä voi tapahtua muun muassa parafiiniöljyruiskutuksin. Parafiiniöljyn teho on osoittautunut kuitenkin heikohkoksi, parhaimmillaankin teho on vain 50 prosenttia (Tiilikkala 1993). Maalevintäinen maltokaarivirus (moptop) on ongelmallinen perunantuotannossa. Se kulkeutuu viljelmältä toiselle siemenperunan ja maa-aineksen mukana. Maassa sitä siirtää mukuloihin kuorirokkoa aiheuttava sieni (Sponcospora subterranea), joka myös säilyttää virusta kestoitiöissään vuosikymmeniä. Siemenperunassa ei saa esiintyä maltokaarivirusta. Suomessa pelkästään siemenperunantuotannossa virustorjunta ja virustautiriskit aiheuttavat runsaan 250000 euron vuotuiskustannukset. Tämä nostaa siemenperunan hintaa 1,7 prosenttia. Virustaudit perunalla lisääntyvät merkittävästi silloin kun perunan tarjontaketju pitenee. Tämän johdosta Suomessa on perunantuotannon tukijärjestelmällä pyritty lyhentämään tarjontaketjua ohjaamalla ruokaperunantuottaja uusimaan siemenkantaansa. Geeniteknologian käyttöönotto voi siten merkitä paineita siemenen uusimisvelvoitteen muuttamiseksi.

Suomessa virustautien merkitys on vähäinen verrattuna esimerkiksi Keski- ja Etelä-Euroopan perunantuotantoon. Siksi geenitekniikan hyödyt ovat suurempia Keski-Euroopassa. Geenitekniikka saattaa siten suurempien kustannussäästöjen takia aiheuttaa kilpailuetua Keski-Euroopan perunantuotannolle, mikä voi vaikuttaa perunan tuontimääriin.

Uusia sienitauteja ilmestyy perunalle jatkuvasti ja perunan sienitautien vastustuskyky on osoittautunut vaikeaksi tavoitteeksi kasvibioteknologiassa (Lorito et all 1998) Rutonkestävyys kasveissa ei ole pelkästään yhdestä geenistä johtuva vaan se on polygeeninen ominaisuus. Siksi täydellinen rutonkestävyys on vaikeammin saavutettavissa kuin täydellinen viruksenkestävyys. Mikäli geenitekniikan avulla voitaisiin edes osittain alentaa torjunta-ainekäyttöä perunaruton torjunnassa, 
tulisi sillä olemaan kuitenkin taloudellisesti suurempi merkitys kuin virustautien torjunnassa. Perunarutontorjunta aiheuttaa työkustannuksineen siemenperunantuottajalle keskimäärin 184 euron hehtaarikustannuksen, joka nostaa siemenperunan hintaa kaksi prosenttia. Ruokaperunantuotannossa rutontorjunta aiheuttaa keskimäärin 148 euron tuotantokustannuksen, joka on 1,8 prosenttia tuotantokustannuksesta ja tärkkelysperunantuotannossa 77 euroa, eli 3,5 prosenttia tuotantokustannuksesta. Perunaseitti on ollut myös lisääntyvä ongelma perunantuotannossa. perunaseittiä voidaan torjua peittaamalla perunansiemen. Peittauskustannus työkustannuksineen ja pääomakustannuksineen on noin 0,04 euroa perunakiloa kohti. Käytännössä kaikki siemenperunantuottajat peittaavat oman kantasiemenensä. Siitä huolimatta kahdella prosentilla siemenperunan kasvustotarkastuksissa siemenperunaerä hylättiin tai siemenluokka aleni perunaseitin takia. Tämä riskitekijä aiheuttaa siemenperunantuottajalle 522 euron suuruisen hehtaarikustannuksen, joka nostaa siemenperunan hintaa 3,9 prosenttia.

Perunan bakteeritaudeista merkittävimmät ovat rengasmätä ja tyvimätä. Rengasmätä on luokiteltu vaaralliseksi kasvitaudiksi ja sen esiintymisestä viljelijä on velvollinen ilmoittamaan kasvinsuojeluviranomaisille. Rengasmädän torjunta ja riskit aiheuttavat pelkästään siemenperunantuotannossa runsaan sadan tuhannen euron vuotuiskustannukset. Tämä nostaa siemenperunan hintaa 0,6 prosenttia. Vaikka tyvimätää ei olekaan määritelty vaaralliseksi kasvitaudiksi, aiheuttaa sen torjunta vielä suurempia kustannuksia kuin rengasmädän torjunta. Pelkästään siemenperunantuotannossa tyvimädän torjunta ja riskit nostavat siemenperunahehtaarin tuotantokustannuksia 636 euroa ja siemenperunan hintaa 4,8 prosenttia.

Peruna herbisidikestävyys, ennen kaikkea glyfosaattikestävyys, on ollut yksi tutkituimpia aiheita geenitekniikkatutkimuksissa (Cockburn \& Tencalla 2003). Rikkakasvitorjunnassa ei geenitekniikalla saavuteta lyhyellä aikavälillä suuria kustannussäästöjä, koska torjunta-aineet vain vaihtuvat muista torjunta-aineista glyfosaatiksi. Toisaalta glyfosaatin teho saattaa olla muita torjunta-aineita parempi ja optimaalinen ruiskutusajankohta voi olla pidempi kuin muilla torjunta-aineilla. Lisäksi pitkällä aikavälillä glyfosaatin käyttö saattaa vähentää pysyvästi joidenkin rikkakasvien populaatiota pellossa, jonka johdosta torjunta-ainekäyttöä voidaan vähentää (Cockburn \& Tencalla 2003).

Tuholaisten vastustuskyky on alue, joka on saavuttanut paljon huomiota tutkijoiden piirissä. Ankeroisten vastustuskyky on ollut tukittavana monissa EU-projekteissa (NONEMA) (Hofvander 2003) Monsanto on vuonna 1995 jalostanut perunalajikkeen koloradonkuoriaista vastaan. Tosin jotkut tutkijat ovat olleet skeptisiä geenitekniikan mahdollisuuksiin koloradonkuoriaisia vastaan. Yhdysvalloissa käytetään vuosittain keskimäärin 350 dollaria hehtaaria kohti pelkästään koloradonkuoriaisen torjuntaan (Thill 2003, ks. myös Heikkilä ja Peltola 2003). Jos koloradonkuoriainen pääsisi leviämään Suomeen ja kykenisi täysin talvehtimaan Suomessa merkitsisi se samalla hehtaarikustannuksella noin 10 miljoonan euron vuotuiskustannuksia yhteiskunnalle.

Pelkästään kasvinsuojelu sekä rikkakasvien kasvitautien ja tuholaisten aiheuttamat riskit aiheuttavat työ- ja pääomakustannuksineen siemenperunantuotannossa 815 euron lisäkustannuksen hehtaaria kohti. Tämä nostaa siemenperunan hintaa 13 prosenttia. Ruokaperunantuotannossa kasvinsuojelun kustannus on 498 euroa, joka on 5,7 prosenttia tuotantokustannuksesta.

\section{Johtopäätökset}

Perunan tarjontaketju on pitkä ja monisäikeinen. Esimerkiksi ruokaperunan tarjontaketju alkaa jalostuksesta, koeputkiviljelyksestä ja esiperussiementuotannosta ja jatkuu perussiementuotannosta sertifioidun siemenen tuotannon kautta perunantuottajan omaan siemenlisäysviljelyyn, ruokaperunantuotantoon ja edelleen tukkukauppojen ja vähittäiskauppojen kautta kuluttajille. Torjunta-aineiden käytön vähentämisen myötä kustannussäästöjä muodostuu monessa eri kohdassa tarjontaketjua. Geenitekniikan omaksuminen perunatiloilla ei vaadi lopulta suuria investointeja, koska investoinnit rajoittuvat uusiin siemeniin. Siemenperunan hinta ja siemenistä maksettavat rojaltit toki kasvavat. Tällä tavoin siemenperunan jalostaja kerää alkuvaiheessa osan perunantuotannossa saavutettavista hyödyistä itselleen. Myös tarjontaketjun muut osapuolet saavuttavat kustannussäästöistä aiheutuvia hyötyjä, muuten he eivät omaksuisi uutta teknologiaa. Voittojen siirtyminen tarjontaketjussa on riippuvainen informaatiosta. Jos informaatio tarjontaketjussa on täydellistä, perunan jalostaja kykenee keräämään siemenen hinnassa ja rojaltien muodossa koko geenitekniikasta saavutettavan hyödyn itselleen. Geenitekniikan käyttöönotto todennäköisesti aiheuttaa tarjontaketjun verkottumista. Näin kävisi ennen kaikkea siksi, ettei geenimuokattua perunaa haluta päästää kilpailijoiden käsiin. Tämän tyyppisestä verkostoitumisesta on viitteitä nykyäänkin perunan tarjontaketjussa: tällä hetkellä kysytyimpien perunalajikkeiden siementuotanto on muutamien lajike- 
edustajien hallussa. Kukin lajike-edustaja edustaa omia siemenperunalajikkeita, joiden viljely ja markkinointi ovat mahdollista vain sellaisella markkinointiyhtiöllä tai siemenperunantuottajalla, joilla on lajike-edustajan kanssa sopimus kyseisten lajikkeiden viljelystä ja markkinoinnista. Näistä lajikkeista siemenperunantuottaja maksaa rojaltia perunan jalostajalle tai jalostajan yhteistyökumppanina toimivalle lajike-edustajalle. Tällaisten lajikkeiden osuus oli 73 prosenttia vuonna 2001 tuotetusta ruokaperunan siemenestä. Tämä osuus on kaksinkertaistunut vuodesta 1994 siitä huolimatta, että kyseisten lajikkeiden siemen oli ainakin rojaltin määrän verran kalliimpia kuin ns. vapaiden lajikkeiden siemenet (Tuomisto 2003). Tämä antaa viitteitä myös siihen, että geenimuokattujen perunalajikkeiden tullessa markkinoille niitä kykenevät viljelemään ainoastaan sellaiset viljelijät, joilla on tuotantosopimus lajike-edustajan kanssa.

Jos geenimuokattua perunaa kyetään tuottamaan alhaisemmilla tuotantokustannuksilla, joita voidaan saavuttaa muun muassa torjunta-ainekustannuksia pienentämällä, saavat niiden tuottajat kilpailuedun suhteessa sellaisiin viljelijöihin, jotka viljelevät perinteisiä lajikkeita. Tämä merkitsee pitkällä aikavälillä perinteisten lajikkeiden väistymistä tuotannosta. Kuluttajien vastustus gm-ruokaa kohtaan voi hidastaa tätä kehitystä. Lyhyellä aikavälillä myös geenimuokattujen tuotteiden erillään pito, merkitseminen ja valvonta lisäävät geenimanipuloitujen elintarvikkeiden tuotantokustannuksia, jotka vähentävät geenimanipuloitujen elintarvikkeiden kilpailuetua. Kun lopulta geenimanipuloitujen elintarvikkeiden määrä markkinoilla kasvaa, nämä kustannukset samalla alenevat ja geenimanipuloidut tuotteet saavat yhä vankemman jalansijan. Pitkällä aikavälillä myös geenimanipuloitua perunaa on tarjoamassa markkinoille useampi jalostaja ja markkinointiyhtiö. Tällöin kilpailu vähentää jalostajien ja lajike-edustajien keräämiä rojalteja ja samalla alentaa tuotetun perunan hintaa. Lopullinen hyötyjä on kuluttaja.

\section{Kirjallisuus}

Bullock, D. and Nitsi, E. 2001. Roundup Ready Soybean Technology and Farm Production Costs: Measuring the Incentive to Adopt. American Behavioral Scientist 44: 1283-1301.

Cockburn, A. and Tencalla, F. 2003. How foods derived from genetically modified crops are tested for safety. A poster and term paper presented at the $7^{\text {th }}$ ICABR Conference in Ravello, Italy, June 29 to July 3, 2003.

Desquilbet, M., Lemarie, S. and Levert, F. 2001. Potential Adoption of GM Crops in France, Effects on Revenues of Farmers and Upstream Companies: An Ex-ante Evaluating. A paper presented at the $5^{\text {th }}$ ICABR Conference in Ravello, Italy, June 15-18, 2001.

Galbraith, J.K. 1952. American Capitalism. The Concept of Countervailing Power. Boston: Houghton Mifflin.

Heikkilä, J. ja Peltola J. 2003. Conceptualising the economics of plant health protection against invasive pests. Agricultural Food and Science in Finland. Vol 12 (2003): 67-81. Helsinki

Hofvander, P. 2003. Potato biotechnology - achievements and opportunities. Proceedins from a Nordic seminar: Potato as Food,. Editors: Vorne, V and Hallikainen, A. Helsinki 26-27.November. 2001. p. 80-85.

Lorito, M., Woo, S.L., Fernandez, I.G., Colucci, G., Harman, G.E., Pintor-Toro, J.A., Filippone, E., Muccifora, S., Lawrence, C.B., Zoina, A., Tuzun, S., and Scala, F. 1998. Genes from mycoparasitic fungi as a source for improving plant recistance to fungal pathogens. Proc. Natl. Acad. Sci. USA 95: 7860-7865.

McBride, W. and Books, N. 2000. Survey of Evidence on Producer Use and Costs of Genetically Modified Seed. In: Lesser (ed.). Transition in Agbiotech: Economics of Strategy and Policy. Proceedings of the NE-165 Conference, Washington D.C. June 24-25, 1999, p. 22-40.

Niemi, J. Mäkelä, S. Tuomisto, J 2003. The Distribution of Costs and Benefits from the Commercial Introduction of Genetically Modified Crops: A Case Study on Potato in Finland. A paper presented at the $7^{\text {th }}$ ICABR Conference in Ravello, Italy, June 29 to July 3, 2003.

Thill, C.A. 2003. Perunanjalostuksen pohjoisamerikkalaiset kehitysnäkymät. Luento Suomen Perunaseuran Kesäseminaarissa Oulussa 30.7.2003. Christian A. Thill, Minnesotan Yliopisto, USA.

Tiilikkala, K. 1993. Perunan tuholaiset ja niiden torjunta/kirvat. Perunan kasvinsuojelu. Maaseutukseksuten liiton julkaisuja 859. Helsinki.

Turunen, H. 2001. Perunantuotannon tilamallit. Maa- ja elintarviketalouden tutkimuskeskuksen (MTT) taloustutkimuksen (MTTL) selvityksiä 23/2001. 62 p. Helsinki.

Tuomisto, J. 2003. Siemenperunan sopimustuotanto Suomessa. Sopimustuotanto siemenperunan markkinaepävarmuudesta aiheutuvan hyvinvointitappion alentajana. MTT Taloustutkimuksen tutkimuksia, Maaja elintarviketalous 22/2003. Helsinki 109 s.+ 17 liitettä.

Tuomisto, J. ja Antila E. 2001. Tärkkelysperunan kannattavuusvertailu tilamallien avulla. Tärkkelysperunantuotannon käsikirja 17.10.2001 (Päivitetty 14.2.2002) Seinäjoki.

Virolainen, M. 2001. Geenitekniikan omaksumisen taloudelliset vaikutukset Suomen elintarvikeketjussa. Casetutkimukset rypsistä ja perunasta MTT taloustutkimuksen (MTTL) selvityksiä 19/2001. Helsinki: MTT taloustutkimus. $49 \mathrm{~s}$. 